\title{
METODE-METODE IDENTIFIKASI KARAKTERISTIK DAERAH TANGKAPAN AIR SUNGAI BAWAH TANAH DAN MATAAIR KAWASAN KARST: SUATU TINJAUAN
}

\author{
Ahmad Cahyadi ${ }^{1}$, Elok Surya Pratiwi², Hendy Fatchurohman ${ }^{3}$ \\ ${ }^{1}$ Magister Perencanaan Pengelolaan Pesisir dan Daerah Aliran Sungai (MPPDAS) \\ Fakultas Geografi Universitas Gadjah Mada \\ 1,2,3 Jurusan Geografi Lingkungan, Fakultas Geografi, Universitas Gadjah Mada \\ Email:1ahmadcahyadi@geo.ugm.ac.id
}

\begin{abstract}
INTISARI
Proses perkembangan sistem hidrologi di kawasan karst yang dipengaruhi oleh loronglorong pelarutan menyebabkan kondisi anisotropis pada airtanah. Kondisi ini menyebabkan pendefinisian karakteristik daerah tangkapan air sungai bawah tanah dan mataair di kawasan karst sangat sulit dilakukan. Tulisan ini bermaksud memaparkan beberapa pendekatan yang digunakan untuk mendefinisikan karakteristik daerah tangkapan air sungai bawah tanah dan mataair di kawasan karst. Beberapa metode yang sering digunakan misalnya metode survei dan eksplorasi, metode pelacakan (tracer), serta invers model.
\end{abstract}

Kata Kunci : Karst, Sistem Aliran, Karakteristik Daerah Tangkapan Air

\section{PENDAHULUAN}

Kawasan karst merupakan kawasan yang memiliki keunikan bentuk permukaan bumi/eksokarst dan bentuk di dalam bumi/endokarst (Worosuprojo dkk, 1997). Keunikan tersebut terjadi karena proses pelrutan yang terjadi pada batuan yang mudah larut dengan hujan dan karbondioksida (Ford dan Williams, 1992; Adji dkk, 1999; Veni dan DuChene, 2001). Batsan yang lebih jelas tentang kawasan karst disampaikan oleh White (1988) bahwa kawasan karst paling tidak memiliki tiga ciri, yaitu (1) terdapatnya cekungan-cekungan tertutup, (2) jarangnya atau tidak ditemukannya sungai permukaan dan (3) berkembangnya drainase bawah permukaan dan sistem gua.

Proses pelarutan di kawasan karst telah menyebabkan terbentuknya lorong-lorong pelarutan. Proses tersebut menyebabkan porositas yang dominan adalah porositas sekunder yang anisotropis (tidak sama ke segala arah). Hal ini menyebabkan batas topografi di bagian permukaan bumi tidak berhubungan dengan batas hirologi dari suatu sungai bawah tanah. Padahal, karakteristik ini begitu penting untuk merencanakan pengelolaan lingkungan pada kawasan karst khususnya sungai bawah tanah dan mataair.

Raeisi dan Karami (1997) menyebutkan bahwa sistem aliran di kawasan karst dapat dibagi menjadi dua, yaitu sistem lorong dengan ukuran yang besar (conduit/konduit) dan sistem lorong dengan ukuran yang kecil (diffuse/difus). Meskipun demikian, beberapa ahli seringkali menambahkan sistem difus-konduit atau sistem campuran (Gambar 1). Hal ini didasarkan pada kenyataan bahwa konduit merupakan perkembangan dari difus, sehingga dalam perkembangannya pasti melewati tahapan di mana kedua sistem sama-sama 
dominan pengaruhnya. Tujuan penulisan artikel ini adalah mengkaji metode-metode yang dapat digunakan untuk mengetahui (mendefinisikan) marakteristik daerah tangkapan mataair atau sungai bawah tanah di kawasan karst. Artikel ini juga membahas kelebihan dan kekurangan dari masing-masing metode.

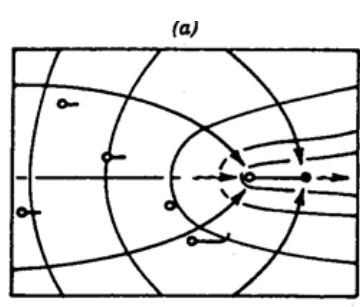

Diffuse

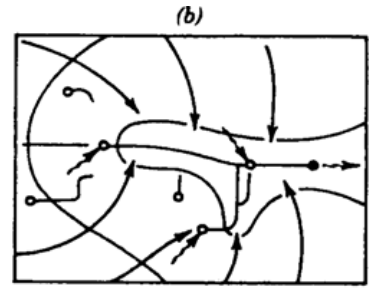

Mixed

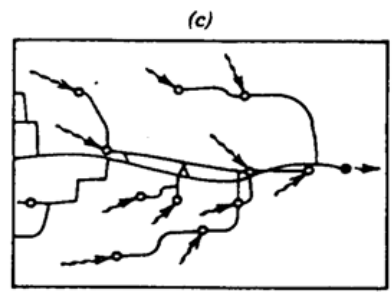

Conduit


Gambar 1. Sistem Hidrologi Kawasan Karst (Domenico and Schwartz, 1990)

\section{METODE-METODE PENDEFINISIAN KARAKTERISTIK WILAYAH TANGKAPAN AIR SUNGAI BAWAH TANAH DAN MATAAIR KAWASAN KARST}

\section{Metode Survei dan Eksplorasi}

a. Analisis Pola Kelurusan (Lineament)

Metode identifikasi karakteristik daerah tangkapan air sungai bawah tanah dan mataair di kawasan karst salah satunya dapat dilakukan dengan menggunakan pendekatan pola kelurusan (lineament). Prinsip berfikir metode ini adalah ketika air hujan sebagai input sungai bawah tanah jatuh di atas permukaan, maka air tersebut akan lebih mudah meresap ke dalam tanah pada kawasan karst melalui jalur pelurusan dan rekahan (fissure) sebagai fissure infiltration. Batuan gamping sebagai batuan utama penyusun topografi karst memiliki tipe porositas yang tidak teratur dan sangat bergantung pada arah dan kedudukan percelahan (cavities) yang terbentuk karena proses solusional, sehingga pada zona pelurusan dan rekahan tersebut sangat berpotensi sebagai daerah tangkapan yang melalukan air ke dalam sistem sungai bawah tanah dan juga mataair.

Teknis pelaksanaan metode ini diawali dengan melihat pola kelurusan yang ada. Pola kelurusan tersebut dapat diketahui dengan teknologi penginderaan jauh (remote sensing) yang kemudian dapat diolah dan direpresentasikan dengan bantuan Sistem Informasi Geografis (SIG). Integrasi antara teknologi remote sensing dan SIG akan menyediakan pengetahuan yang lebih baik secara spasial mengenai sumberdaya 
airtanah karena SIG mampu menampilkan gambaran secara spasial dan akurat dari banyak data spasial dengan sumber berbeda (Sander,1996). Produk remote sensing yang dapat digunakan untuk melihat pola kelurusan di permukaan bumi diantaranya adalah foto udara, citra resolusi tinggi dan sedang serta peta topografi skala besar. Delineasi pola kelurusan melalui foto udara pernah dilakukan oleh Haryono dan Day (2004) yang pada penelitiannya tersebut menggunakan foto udara pankromatik hitam putih skala 1:50.000 (Gambar 2).
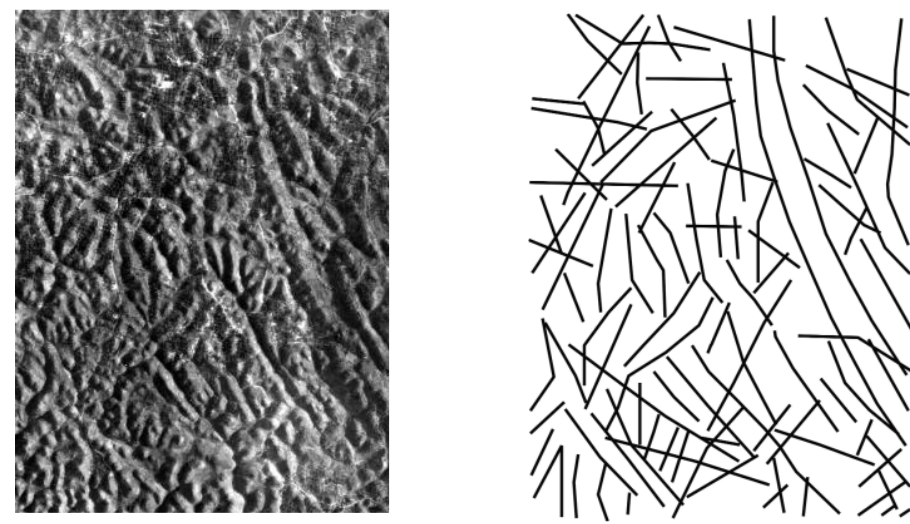

Gambar 2. Pola kelurusan pada topografi karst melalui delinesi foto udara (Sumber: Haryono and Day,2004)

Penelitian dengan analisis kelurusan sebagai pendekatan untuk mengetahui sistem sungai bawah tanah di kawasan karst dengan bantuan teknologi remote sensing dan SIG pernah dilakukan oleh Perizek (1976) dalam Ford and Williams (1992). Pendekatan kelurusan dan retakan tersebut kemudian digunakan untuk menentukan posisi mataair dan lokasi yang tepat untuk membuat sumur. Berdasarkan hasil penelitian tersebut, dapat dilihat distribusi lokasi mataair yang cenderung mengelompok pada zona pelurusan dan perpotongannya. Hal tersebut mengindikasikan bahwa terdapat konsentrasi aliran bawah tanah yang melalui zona pelurusan dan rekahan, sehingga pembuatan sumur sebaiknya masih berada pada jalur pelurusan dan rekahan tersebut.

Analisis menggunakan pendekatan pelurusan dirasa jauh lebih mudah dan sederhana karena pola kelurusan dapat dilihat dengan mudah melalui foto udara, citra resolusi tinggi dan sedang serta peta topografi skala besar yang saat ini mudah diperoleh. Biaya yang dibutuhkan juga tidak terlalu besar karena tidak perlu menggunakan alat yang khusus, hanya mungkin biaya dikeluarkan untuk membeli foto udara, citra atau peta topografi. Biaya yang cukup besar justru akan dikeluar untuk keperluan crosscheck lapangan. Meskipun demikian, analisis pola kelurusan hanya bersumber dari kondisi permukaannya saja, sedangkan kondisi bawah permukaan tidak dapat dibuktikan dengan metode ini. 


\section{b. Analisis Geofisika}

Survei penelitian yang bertujuan untuk mengetahui kondisi di bawah permukaan bumi khususnya dalam hal ini adalah kondisi sistem sungai bawah tanah di kawasan karst dapat pula dilakukan dengan metode geofisika. Metode geofisika untuk mengetahui kondisi bawah tanah dilakukan dengan cara pengukuran di atas permukaan bumi dari parameter - parameter fisika yang dimiliki oleh batuan di dalam bumi. Berdasarkan pengukuran tersebut selanjutnya dapat ditafsirkan sifat - sifat dan kodisi di bawah permukaan bumi baik secara vertikal maupun horizontal.

Beberapa metode geofisika yang dapat digunakan untuk mendeteksi jaringan sungai bawah tanah adalah metode geolistrik dan georadar. Kedua metode tersebut termasuk dalam kategori metode aktif yakni dilakukan dengan membuat medan gangguan kemudian mengukur respon dari bumi.

\section{1) Metode Georadar}

Georadar atau Ground Penetration Radar (GPR) merupakan salah satu metode survei dan eksplorasi kondisi di bawah tanah yang menggunakan prinsip geofisiska elektromagnetik. Prinsip kerja GPR adalah dengan memanfaatkan pemantulan sinyal elektromagnetik yang ditembakkan melalui antena pemancar (transmitted signal). Sinyal mengenai objek di bawah tanah dan kemudian dipantulkan kembali (reflected signal) menuju antena perekam (receiver). Perbedaan respon cepat rambat gelombang (amplitudo) pada setiap benda terhadap sinyal gelombang elektromagnetik yang ditembakkan tersebutlah yang menjadi dasar identifikasi jenis benda atau material di dalam tanah. Sifat - sifat fisika benda/material di dalam tanah yang dapat diketahui melalui GPR adalah sifat konduktifitas dan induktansi listrik.

Keberadaan aliran sungai bawah tanah di daerah karst dapat juga diketahui melalui metode ini. Ketika sinyal elektromagnetik yang ditembakkan mengenai suatu benda yang berbeda (heterogen) maka sinyal yang dipantulkan akan besar dan perbedaan cepat rambat yang terekam akan terlihat jelas. Kedalaman sistem sungai bawah tanah juga dapat diketahui karena dalam alat georadar juga merekam kecepatan gelombang elektromagnetik dan waktu tempuh sinyal sewaktu gelombang mulai ditembakkan hingga gelombang tersebut mengenai objek dan memantul kembali ke antena perekam. Ilustrasi cara georadar mendeteksi obyek di dalam tanah disajikan pada gambar 3 . 


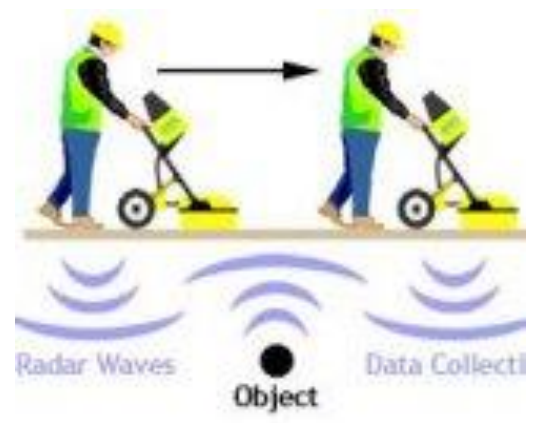

Gambar 3. llustrasi cara kerja georadar atau Ground Penetration Radar (GPR)

(Sumber: http://balitbang.kemhan.go.id/?q=content/aplikasi-teknologi-ground-penetrating-

radar-gpr-untuk-deteksi-struktur-tanah-batuan-dan-mate)

Keunggulan metode survai dan eksplorasi menggunakan georadar adalah terkait dalam hal keakurasian data yang didapat. Metode georadar telah menggunakan teknologi alat yang lebih canggih dibandingkan dengan geolistrik sehingga keakurasian data yang didapat jauh lebih baik dibandingkan dengan metode survai dan ekplorasi dengan metode geolistrik. Namun demikian, biaya yang dibutuhkan untuk melakukan metode ini jauh lebih mahal karena harus menyiapkan pemancar dan antena perekam. Selain itu, pengolahan hasil sinyal gelombang elektromagnetik yang direkam georadar untuk mendapatkan profil penampang vertikal dan horisontal membutuhkan keahlian khusus karena pengolahannya yang cukup rumit.

\section{2) Metode Geolistrik}

Analisis geofisika lebih ditujukan untk mengetahui karakter hidrogeologi. Geolistrik dilakukan dengan prinsip mengukur nilai tahanan jenis (resistivity) pada perlapisan batuan. Masing-masing jenis batuan akan memiliki nilai tahanan jenis yang berbeda. Tahanan jenis juga dipengaruhi oleh porositas, kandungan air hingga kualitas air yang ada di sebuah akuifer.geolistrik lebih banyak digunakan karena pengo[erasiannya mudah dan tidak membutuhkan biaya yang besar. Survey geolistrik dilakukan dengan cara memasang dua jenis elektroda, yaitu elektroda arus dan potensial. Sebagian besar survei geolistrik menggunakan pengukuran dengan 4 elektroda (Gambar 4). Dua elektroda potensial ditempatkan diantara 2 elektroda arus. Arus listrik dialirkan melalui elektroda arus dan elektoda poensial akan mengukur perubahan potensial yang ada dalam tanah. hasil interpretasi geolistrik ini akan menghaislkan data mengenai tahanan jenis material yang ada dalam tanah. semakin jauh bentangan elektroda maka jangkauan interpretasi semakin dalam. (Delleur, 2007 serta Purnama,2010) 
Rumus menentukan tahanan jenis (Todd,1980) :

$$
\mathrm{R}=K \frac{\Delta V}{\mathrm{I}}
$$

$\mathrm{R}$ adalah resitivity, $\mathrm{K}$ adalah konstanta yang diperoleh dari tabel konstanta Schlumberger, konstanta ini menunjukkan jarak elektroda potensial. $\Delta V$ adalah perubahan otensial dan I adalah besarnya arus yang dialirkan (Purnama,2010)

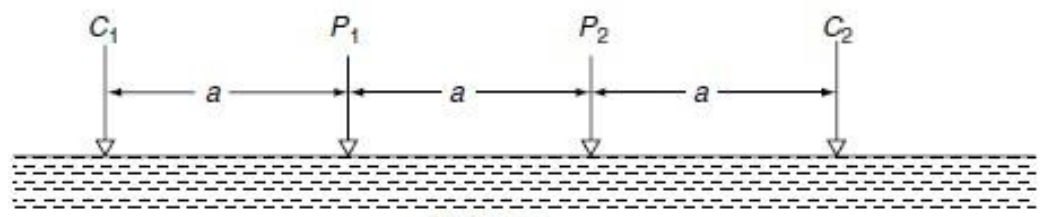

Wenner

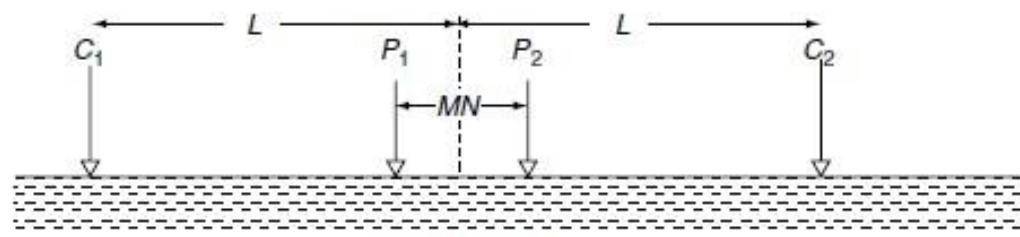

Schlumberger

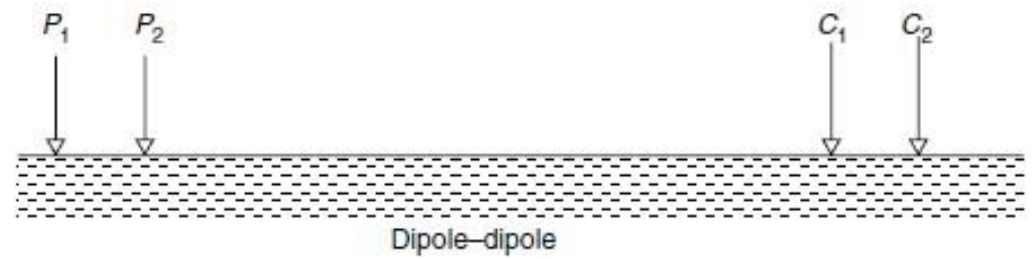

Gambar 4. Berbagai jenis susunan elektroda (Delleur, 2007)

Analisis georadar atau lebih dikenal dengan GPR (Ground Penetrating Radar) adalah metode yang menggunakan energi elektromagnetik dengan frekuensi berkisar antara 10-1000 MHz. Sistem georadar ini terdiri dari generator impuls yang secara teratur mengirim tanda voltase dan sumber frekuensi kepada antena pemancar. Sistem georadar ini mirip dengan prinsip yang mirip metode sismis dan sonar. Pemancar akan mengirimkan radiasi getaran pendek dengan frekuensi tinggi ( $\mathrm{MHz}$ hingga $\mathrm{GHz}$ ). Gelombang elektromagnetik dan antenna penerima akan mengukur karakteristik sinyal sebagai sebuah satuan waktu.Antena akan memancarkan radiasi gelombang baik ke udara dan ke bawah tanah. energi akan merambat ke bawah permukaan tanah dan dipantulkan oleh perbedaan dielektrik yang ada di bawah permukaan tanah.berdasarkan hal tersebut maka dapat dilakukan interpretasi bawah tanah,juga untuk penyelidikan airtanah. Georadar juga dapat digunakan untuk penyelidikan airtanah pada sistem conduit dalam gua.(Delleur, 2007). 


\section{3) Teknik Pelacakan Airtanah Karst (Water Tracing)}

Bentuklahan karst memiliki karakteristik yang khas dengan sistem drainase bawah tanah yang lebih berkembang. Identifikasi jaringan sungai bawah tanah tidak bisa secara langsung diinterpretasi dari permukaan. Salah satu teknik untuk mengetahui jarigan sungai bawah tanah atau hubungan antar goa adalah dengan melacak aliran airtanah di kawasan karst. Teknik pelacakan airtanah karst (water tracing) adalah salah satu cara mengidentifikasi sistem sungai bawah tanah di akuifer karst ( Haryono dan Adji, 2004). Tracer adalah benda atau energi yang dilarutkan dalam air yang berfungsi untuk melacak karakteristik aliran dan kecepatan airtanah. Metode pelacakan airtanah yang pertama kali dilakukan tercatat sekitar 2000 tahun yang lalu saat seorang bernama Phillip melemparkan sekam ke dalam sebuah danau kawah dan melaporkan hasilnya bahwa sekam tersebut keluar di aliran sungai yang ada dai daerah hilir ( Stanley et all, 1980).

Uji tracer dilakukan untuk mengetahui karakteristik akuifer dan sungai bawah tanah di daerah karst. Uji tracer juga bertujuan menentukan arah dan kecepatan aliran airtanah di daerah karst. Water tracing dilakukan dengan menuangkan pelacak jenis tertentu pada aliran air. Aliran air disini dapat berarti air yang ada di permukaan atau air yang akan masuk ke aliran bawah tanah, juga ponor/ sinkhole dengan aliran air di dalamnya. Tracer akan terbawa oleh aliran air, sehingga tanda-tanda tracer dapat diidentifikasi di daerah yang dperkirakan menjadi output dari lokasi yang telah dituangkan tracer sebelumnya Apabila diperoleh tanda-tanda tracer yang dapat diidentifikasi baik secara fisik maupun dengan bantuan alat pengukur maka dapat disimpulkan bahwa terdapat hubungan jaringan bawah tanah antara tempat kita menuangkan tracer dengan tempat kita mengahadang tracer tersebut ( Haryono dan Adji, 2004). Bahan pelacakan yang digunakan harus memiliki berbagai persyaratan agar lebih banyak keuntungan yang diperoleh daripada kerugiannya. Stanley,et.all.(1980) membagi tracer dalam jenis yang cukup kompleks meliputi air panas, spora, substansi ionik, isotop yang stabil, zat radioaktif, gas, florokarbon, dan pewarna alami. Masing-masing jenis tracer ini memiliki karakter khas yang dapat disesuaikan dengan kondisi airtanah yang akan dilacak. Haryono dan Adji (2004) menyebutkan bahwa syarat tracer antara lain :

- Tidak beracun

- Larut dalam air

- Dapat dilakukan dalam jumlah yang tidak terlalu banyak

- Resisten ( tidak merubah reaksi kimia dalam air)

- Tidak dapat terserap oleh batuan

- Tidak terpengaruh reaksi pertukaran ion

- Murah dan mudah dianalisis

\section{c. Invers Model}

Analisis yang banyak digunakan dalam hidrologi permukaan adalah forward modelling (Rehrl dan Birk, 2010). Contoh aplikasi forward modelling adalah analisis karakteristik daerah aliran sungai (DAS) yang merupakan daerah tangkapan air suatu sistem sungai, untuk memperkirakan karakteristik dan sifat aliran pada suatu titik 
pengamatan. Namun demikian, karena karakteristik daerah tangkapan air sungai bawah tanah sulit diketahui karakteristik dan batasnya, maka forward modelling tidak dapat diaplikasikan. Berdasarkan hal tersebut maka kemudian muncul suatu pendekatan atau model yang disebut invers modelling. Invers modelling adalah suatu pendekatan yang berkebalikan dengan forward modelling, di mana karakteristik dan sifat aliran pada suatu titik sungai bawah tanah digunakan untuk mendefinisikan karakteristik dari daerah tangkapan airnya (Gambar 2). Metode-metode invers modelling yang sering digunakan adalah analisis debit aliran (Rehrl dan Birk, 2010 serta Liu dkk, 2004), analisis karakteristik sifat fisika air dan analisis kimia air/hidrogeokimia (Rehrl dan Birk, 2010 serta Liu dkk, 2004).

\section{Spring Catchment}

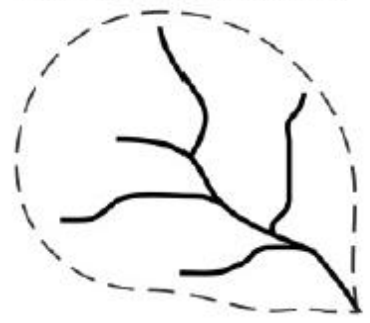

Spring Response

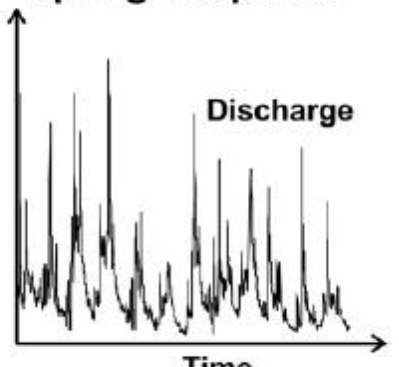

Gambar 2. Perbedaan Forward Modelling dan Invers Modelling (Rehrl dan Birk, 2010)

\section{a. Analisis Hidrograf Mataair dan Sungai Bawah tanah}

Analisis hidrograf mataair dan sungai bawah tanah dapat dilakukan untuk mengetahui karakteristik sistem aliran yang berkembang di suatu kawasan karst. Hal tersebut disebabkan karena masing-masing jenis sistem hidrologi memiliki karakteristik berbeda-beda. Sistem aliran konduit akan memiliki respon terhadap hujan sangat cepat (White, 1989). Hal ini karena pada sistem ini aliran permukaan akan langsung mengalir melalui lubang-lubang pelarutan dengan ukuran yang besar menuju sistem sungai/aliran bawah tanah. Kondisi yang berlainan terjadi pada sistem aliran fisure dan difusse. Sistem aliran fissure memiliki respon lebih lambat dibandingkan konduit karena aliran permukaan akan melewati retakanretakan dengan ukuran yang kecil, sedangkan sistem aliran diffuse akan memiliki respon yang paling lambat karena air permukaan akan mengalir melalui pori-pori batuan gamping (Liu dkk, 2004). Berdasarkan hal tersebut, maka karakteristik sistem aliran dapat diduga dengan karakteristik hidrograf. Misalnya penelitian yang dilakukan oleh Adji (2009) yang menggunakan konstanta resesi aliran konduit, fisure dan diffuse. Dalam penelitian tersebut, konstanta resesi aliran konduit disamakan dengan konstanta channel, konstanta fissure disamakan dengan konstanta interflow, sedangkan konstanta aliran diffuse disamakan dengan konstanta baseflow. 


\section{b. Analisis Kemograf atau Hidrogeokimia}

Metode yang digunakan dalam analisis hidrogeokimia adalah dengan memasang alat pencatat yang mengukur secara real time karakteristik hidrogeokimia aliran. Keterbatasan terhadap alat pencatat ini dipat diatasi dengan melakukan pengambilan sampel pada kasus setelah terjadi hujan sesaat atau dapat pula pengambilan sampel dengan frekuensi tertentu. Unsur-unsur yang sering digunakan adalah nilai unsur-unsur mayor khusunya $\mathrm{HCO}_{3}$ - serta karbon organik dan anorganik. Hasil perhitungan kandungan unsur-unsur yang dikaji baik dengan alat ataupun melalui laboratoeium kemudian dipasangkan dengan data debit, hujan dan dapat pula dengan karakteristik fisika air dalam aliran sungai bawah tanah. Variasi temporal kandungan unsur yang dianalisis akan menunjukkan karakteristik hidrogeokimia aliran terhadap musim, karakteristik hidrogeokimia aliran terhadap hujan dan pula dilakukan dengan analisis pengaruh debit terhadap hidrogeokimia aliran.

Daerah tangkapan air yang didominasi oleh sistem aliran diffuse akan memiliki variasi kandungan kimia yang kecil dibandingkan dengan daerah tangkapan air yang didominasi oleh konduit. Sistem aliran diffuse biasanya memiliki jumlah imbuhan airtanah yang lebih sedikit dibandingkan konduit, serta memiliki luas wilayah tangkapan air yang kecil. Variasi total kesadahan pada aliran diffuse biasanya kurang dari 5\% (Raesi dan Karami, 1997). Selain itu, karakteristik dari sistem diffuse adalah bahwa kandungan karbon organik sangat sedikit dengan variasi musiman sangat kecil pula. Kandungan $\mathrm{HCO}_{3}$ - tinggi dan memiliki variasi yang kecil antara musim penghujan dan kemarau. Karakteristik lain adalah sedikitnya total disolved solid dengan variasi musiman yang rendah pula.

Berbeda dengan karkteristik sistem aliran diffuse, aliran konduit memiliki imbuhan air yang banyak dan memiliki wilayah tangkapan yang luas. Karena didominasi oleh lorong-lorong pelarutan dengan diameter yang cukup besar, maka sistem aliran ini akan memiliki respon terhadap hujan cepat. Variasi kandungan kimia pada sistem aliran ini besar hingga sangat besar. Kandungan karbon organik sangat tinggi pada musim hujan dan menjadi sangat sedikit ketika musim kemarau. Kandungan $\mathrm{HCO}_{3-}$ tinggi pada musim kemarau sedangkan pada musim hujan terjadi pengenceran sehingga kansungan $\mathrm{HCO}_{3}$ - menjadi kecil. Raesi dan Karami (1997) mengatakan bahwa variasi total disolved solid pada sistem aliran konduit dapat mencapai $10-24 \%$.

\section{KESIMPULAN}

Metode-metode yang disampaikan pada tulisan ini hanya merupakan suatu pendekatan, sehingga belum mampu menggambarkan secara pasti dari karakteristik sistem aliran secara detail. Oleh karena itu, maka penggunaan lebih dari satu metode akan memberikan hasil yang lebih akurat. Selain itu, penggunaan metode yang telah dipaparkan hendaknya tetap mengingat pada asumsi-asumsi yang digunakan. 


\section{DAFTAR PUSTAKA}

Adji, Tjahyo Nugroho; Haryono, Eko; dan Woro, Suratman. 1999. Kawasan Karst dan Prospek Pengembangannya. Makalah dalam Seminar Pertemuan IImiah Tahunan Ikatan Geografiwan .Indonesia 1999. Universitas Indonesia, 26-27 Oktober 1999.

Adji, T.N. 2009. Variasi Spasio-Temporal Hidrogeokimia dan Sifat Aliran untuk Karakterisasi Sistem Karst Dinamis di Sungai Bawah Tanah Bribin, Kabupaten Gunung Kidul, DIY. Disertasi. Fakultas Geografi UGM Yogyakarta.

Delleur, Jacques W. 2007. The Handbook of Groundwater Engineering-Second Edition. London : CRC Press.

Domenico,Patrick A. dan Schwartz, Franklin W. 1990. Physical and Chemical Hydrogeology. Edisi Kedua. New York: John Wiley \& Sons.

Ford, D. dan Williams, P. 1992. Karst Geomorphology and Hydrology. London: Chapman and Hall.

Haryono, E and Day, M. 2004. Landform differentiation within the Gunung Kidul Kegelkarst, Java, Indonesia. Journal of Cave and Karst Studies, v. 66, no. 2, p.62-69.

Haryono,E dan Adji,T.N. 2004. Geomorfologi dan Hidrologi Karst. Yogyakarta : Fakultas Geografi UGM

Liu, Zaihua; Groves, Chris; Yuan, Daoxian and Meiman, Joe. 2004. South China Karst Aquifer Storm-Scale Hydrochemistry. Ground Water, Vol. 42(4). Hal: 491-499.

Murwanto, E.J. 2011. Aplikasi Teknologi Ground Penetrating Radar (GPR) untuk Deteksi Struktur Tanah/Batuan dan Mineral Terpendam. Diakses Oleh Elok Surya Pratiwi Tanggal 12 Juli 2012, Pukul $15.30 \quad$ WIB dari http://balitbang.kemhan.go.id/?q=content/aplikasi-teknologi-ground-penetrating-radargpr-untuk-deteksi-struktur-tanah-batuan-dan-mate

Raeisi, Ezzatollah dan Karami, Gholamhosein. 1997.Hydrochemographs Of Berghan Karst Spring As Indicators Of Aquifer Characteristics. Journal of Cave and Karst Studies, Vol. 59(3). Hal: 112-118.

Rehrl, Christoph dan Birk, Steffen. 2010. Hydrogeological Characterisation and Modelling of Spring Catchments in a Changing Environment. Austrian Journal of Earth Sciences, Vol. 103 (2). Hal: 106-117.

Sander, P. 1996. Groundwater Assessment Using Remote Sensing and GIS in A Rural Groundwater Project In Ghana: Lesson Learned. Hydrogeology Journal, Volume 4(3).

Stanley,N. Davis,Glen M. Thomson, Harold W. Bentley, and Gary Styles.1980.Groundwater Tracers-A Short Review.Groundwater Journal vol.18 No.1 January-February 1980. Hal 14-21

Veni, George dan DuChene, Harvey. 2001. Living with Karst: A Fragile Foundation. Alexandria: American Geological Institute.

White, William B. 1989. Geomorphology and Hydrology of Karst Terrains. New York. Oxford University Press.

Worosuprojo, S.; Suyono; Risyanto; Adji, T.N. 1997. Kajian Ekosistem Karst di Kabupaten Gunungkidul Provinsi Daerah Istimewa Yogyakarta. Laporan Penelitian. Biro Bina Lingkungan Hidup Provinsi Daerah Istimewa Yogyakarta dan Fakultas Geografi Universitas Gadjah Mada. 
Makalah ini merupakan salah satu chapter dalam buku berjudul "Pengelolaan Lingkungan Zamrud Khatulistiwa”, dengan Editor Muh Aris Marfai dan M. Widyastuti. Buku ini diterbitkan di Yogyakarta Tahun 2013 oleh Penerbit Pintal. Makalah ini dimuat di halaman 50-61. 